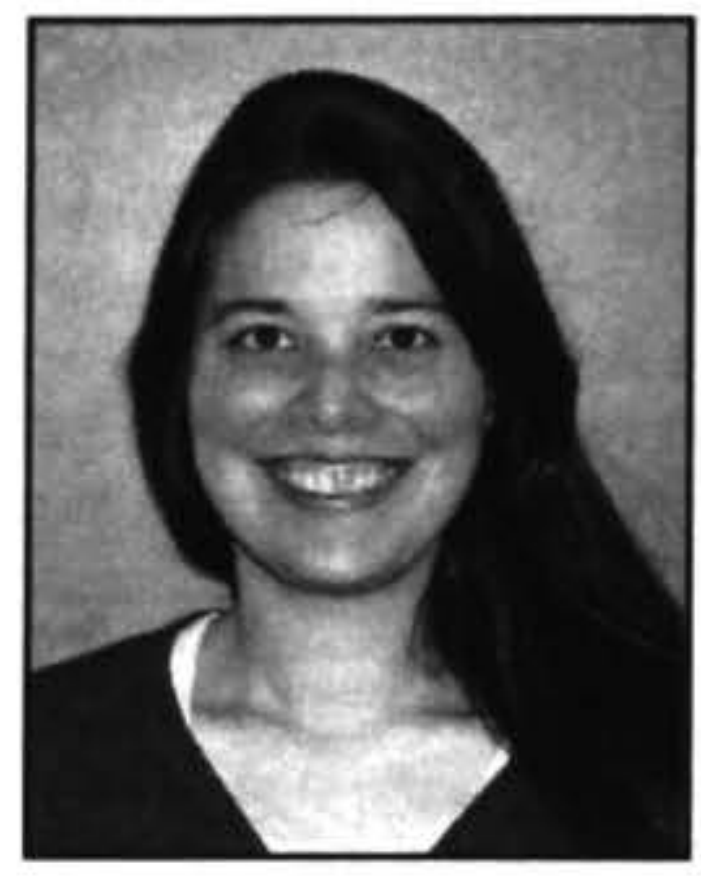

\title{
UNEMPLOYMENT DYNAMICS IN NEW ZEALAND
}

\author{
Maria Gobbi \\ Labour Market Policy Group \\ Department of Labour
}

David Rea

Policy Department

Ministry of Social Policy

\begin{abstract}
In this paper, we analyse the experiences of the unemployed by looking at what happened to groups of job seekers over a four year period. In particular, we focus on job seekers who either registered as unemployed with the New Zealand Employment Service in 1993, or left the unemployment register in 1993. Overall, our analysis showed that there was considerable variation in how individuals experienced unemployment. For a quarter of job seekers, unemployment was a singular and relatively brief experience. However, by way of contrast, a quarter of job seekers also experienced chronic unemployment often in repeated spells. In addition, unemployment experiences tended to vary for different social groups and across time with the economic cycle.
\end{abstract}

Keywords: Unemployment, unemployment experiences, unemployment spell, duration of unemployment, non-unemployment spell, total time spent unemployed

Prolonged unemployment is not consistent with a well functioning labour market. If the labour market was functioning effectively, we would expect some level of unemployment as part of the matching of job seekers and vacancies. However, under such conditions we would expect that the time spent unemployed should be relatively brief.

Individuals spending long periods of time unemployed is evidence of a failure of the labour market to match workers and vacancies. This failure has both efficiency and equity implications. From an efficiency perspective, the failure means that the economy has lower output and households have lower incomes. From an equity perspective, the failure means that the burden of unemployment is borne disproportionately by various groups.

Prolonged unemployment is therefore a major social and economic problem. Not only does unemployment reduce current and future economic output, but joblessness leads to considerable social distress for individuals and communities.

To look at issues such as prolonged unemployment, it is important to try to measure the actual experiences of the unemployed. However, in New Zealand there has been little research focussing on these experiences. Instead information on unemployment has been based on measures of unemployment at a point in time or measures of the numbers of people becoming unemployed or leaving unemployment. Such approaches provide useful information on unemployment overall but little information on the experiences of the unemployed.

In our research, we examine experiences or patterns of unemployment using administrative data. The paper reports on descriptive results from a unit record data set of the registered unemployment experiences of job seekers over the period from October 1988 to December 1997. These descriptive results provide interesting insights into the different nature of unemployment experiences. The study is motivated by a number of research questions:

1. Is unemployment randomly distributed amongst the population, or is unemployment only experienced by a small core of the population?

2. How do individuals typically experience unemployment?

3. Which groups are more at risk of prolonged or frequent experiences of unemployment?

4. How do experiences of unemployment change over the business cycle?

The rest of the paper is structured in the following man- 
ner. We start by describing our data set and then we briefly look at the unemployment experiences for all job seekers who either became registered unemployed, or who left registered unemployment in 1993 . Next we look at how these results vary for different social groups. Finally, we look at how our overall results on the experiences of the unemployed vary across time.

\section{Dataset}

There has, historically, been relatively ad hoc information about the unemployment experiences of individual job seekers. The absence of good information has hampered the ability of policy makers to analyse both the nature of unemployment and the effectiveness of employment policy. To provide better information on the distribution and dynamics of unemployment, we have assembled the unemployment dynamics data set, which is based on the administrative information previously collected by the New Zealand Employment Service (NZES).

Our data set contains comprehensive information on the unemployment history of each job seeker who was registered unemployed over the period October 1988 to December 1997 . The data set records that roughly $1.2 \mathrm{mil}-$ lion individuals experienced unemployment over this period. To put this another way, slightly more than a third of the working age population who were resident in New Zealand at some point in time during the nine years experienced unemployment.

It is important to note that 'registered unemployment' is somewhat different from the official measure of 'surveyed unemployment.' Registered unemployment data is a measure of the number of people who have indicated that they would like to have assistance from the Government to find employment as well as the number of people who are required to do so because they are in receipt of a work tested benefit. The official measure of unemployment is derived from the Household Labour Force Survey (HLFS) and classifies individuals as unemployed when they are actively searching and available for employment. This official measure provides a stricter criterion for defining an individual as unemployed, and hence the numbers of surveyed unemployed are typically less than registered unemployed. For example, the register can include individuals who work part-time, while official unemployment does not. In March 1993, official unemployment was close to 170,000 , while registered unemployment was close to 220,000 .

\section{Measuring the experiences of the unemployed}

Our analysis shows that there is a wide variety of patterns of unemployment experience. Three hypothetical experiences of unemployment are represented in Figure 1. Individual 'A' experiences multiple spells of unemployment, while individual ' $B$ ' experiences one long spell of unemployment. Individual ' $C$ ' does not experience unemployment at all.

In order to describe the differing patterns of registered unemployment, we have developed on five different measures. These are:

1. The proportion of the working age population who become unemployed (at least once) in a given year;

2. The length of time that a job seeker spends unemployed in their first spell of unemployment;

3. The length of time between finishing a spell of unemployment and starting a new spell;

4. The number of spells of unemployment in a four year window of time;

5. The total time spent unemployed in a four year window of time.

To ensure that we control for the effect of changing economic circumstances, we focus on cohorts of job seekers who either started or finished a spell of unemployment in 1993. We then are able to follow the unemployment experiences of these individuals for the next four years.

\section{Figure 1. Illustrative Example of Unemployment Patterns}

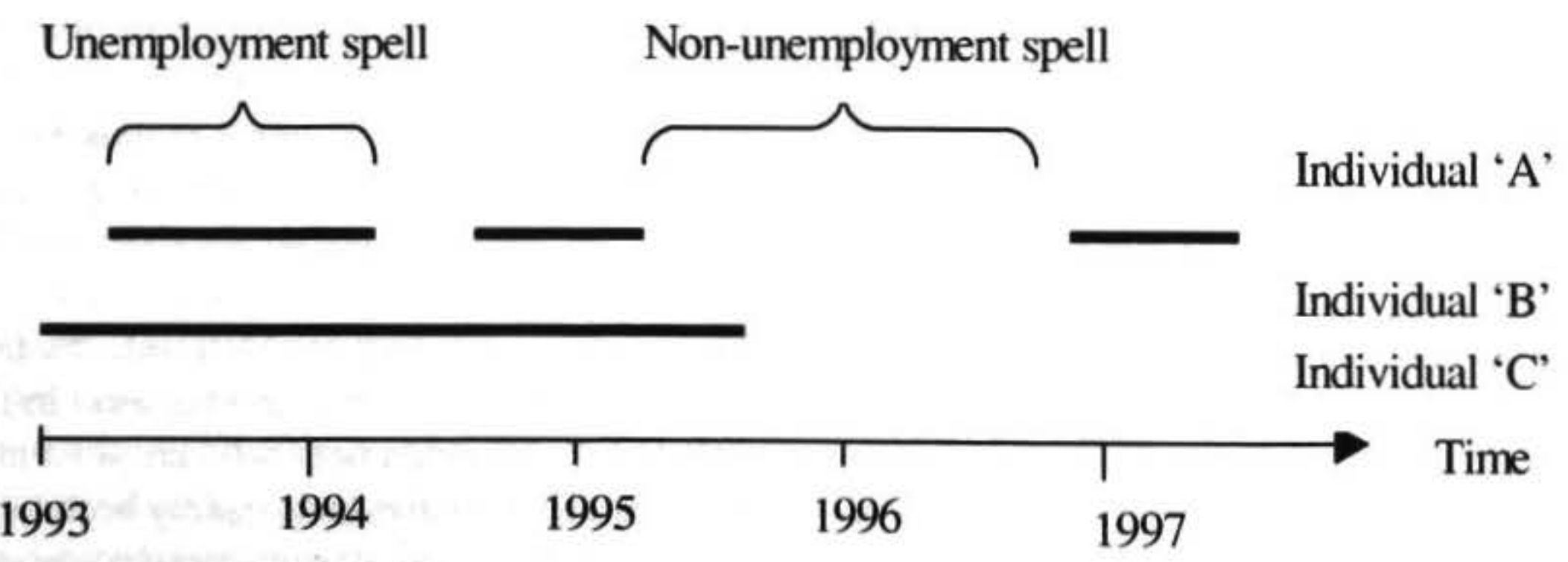




\section{The Unemployment Experience}

In 1993 slightly more than 250,000 individuals became registered unemployed. This means that approximately $9.7 \%$ of the working age population experienced unemployment at least once during the year and around $15 \%$ of the labour force. This seems to indicate that the experience of unemployment is reasonably widely shared amongst the working age population in any given year.

Typically, each job seeker tended to be unemployed for close to five months of the following four years. For the 1993 cohort, the typical length of the first spell of unemployment - as measured by the median - was 19 weeks. There was, however, considerable variation in the length of unemployment spells for different job seekers. This is shown in Table 1which ranks every job seeker in the cohort by the length of their first unemployment spell. For example, consider the $10^{\text {th }}$ percentile of 5.9 weeks and the $90^{\text {th }}$ percentile of 66.9 weeks. This means that only $10 \%$ of all job seekers had a duration of unemployment that was shorter than 5.9 weeks, and $10 \%$ of all job seekers had a duration of unemployment that was 66.9 weeks or longer.

Another important result in Table 1 is that the majority of job seekers experience relatively short duration's of unemployment, while a minor ity of job seekers experience much longer spells of unemployment. For example, approximately $60 \%$ of job seekers experience spells less than 26 weeks of unemployment. By way of contrast, around $20 \%$ of job seekers experience spells of unemployment of 43 weeks or longer.

Table 1. Duration of First Unemployment Spell for the 1993 Cohort

\begin{tabular}{cc}
\hline Percentiles & Length of unemployment spell \\
\hline 10 & 5.9 weeks \\
20 & 9.0 weeks \\
30 & 9.6 weeks \\
40 & 13.7 weeks \\
50 & 18.7 weeks \\
60 & 25.6 weeks \\
70 & 30.7 weeks \\
80 & 42.9 weeks \\
90 & 66.9 weeks \\
\hline
\end{tabular}

Another perspective on the duration of the single spell of unemployment is to focus on the probability that a job seeker will leave the register, given that they have reached a particular duration. This data indicates that generally the longer a job seeker is unemployed, the less likely they are to move out of unemployment. Overseas research indicates that there are likely to be two key explanations for this result.

The first explanation is referred to as the 'heterogeneity hypothesis'. This hypothesis is that as the duration of unemployment increases, the proportion of low risk job seekers declines (because they find employment), and this leaves a greater proportion of high-risk individuals. The second explanation of the declining risk of leaving unemployment is of more concern, and is often referred to as the 'duration dependence' hypothesis. The longer unemployment lasts, the more likely it is that job seekers will become discouraged from active job search and less employable because of poor attitudes or outdated skills. It is not possible to conclusively show which of these explanations is driving the New Zealand results.

\section{Times between Unemployment Spells}

An important finding of our research to date is that after finishing their first spell of unemployment, most job seekers tend to become unemployed again. Typically, individuals become unemployed again within a year and a half after finishing their spell of unemployment. However, there is significant variation in how long it takes before job seekers become unemployed again. As can be seen from Table 2 , roughly $30 \%$ of job seekers become unemployed again within 23 weeks. By way of contrast, slightly more than $30 \%$ are not observed to become unemployed again (at least within the four year window in which we are measuring).

\section{Table 2. Time between Unemployment Spells, Job Seekers who Ended a Spell of Unemployment in 1993}

\begin{tabular}{cc}
\hline Percentiles & $\begin{array}{c}\text { Length of off-register spell in } \\
\text { weeks }\end{array}$ \\
\hline 10 & 7.4 \\
20 & 14.0 \\
30 & 23.3 \\
40 & 37.9 \\
50 & 74.6 \\
60 & 172.0 \\
70 & Do not return within 4 years \\
80 & Do not return within 4 years \\
90 & Do not return within 4 years \\
\hline
\end{tabular}

Another perspective on the length of the off-register spell is to analyse the risk of becoming unemployed at different durations. This is also a hazard curve - but in this case the hazard curve represents the risk of becoming unemployed at different durations after ending a spell of unemployment. Our analysis indicates that, immediately after finishing a spell of unemployment, there is a very high risk of becoming unemployed again. However, this risk declines rapidly until after the first year. After that time, there is a low and relatively constant risk of becoming unemployed again. Overseas research indicates that there are two key explanations for the observation that the risk of becoming unemployed seems to decline the longer an individual is off the unemployment register.

The heterogeneity hypothesis proposes that there is a mixture of different types of job seekers. Initially there are a lot of high-risk individuals who are susceptible to unemployment. These individuals rapidly become unemployed, leaving only those low-risk individuals who are unlikely to experience unemployment again. The alternative hy- 
pothesis is duration dependence. This hypothesis predicts that the risk of becoming unemployed will decline as individuals become more employable and accustomed to the world of work. This might occur, for example, because individuals in jobs accumulate more social networks, skills and experience that makes becoming unemployed less likely. As noted above, it is not possible to conclusively show which of these explanations is driving the New Zealand results.

\section{Number of Unemployment Spells}

The fact that a relatively high proportion of job seekers become unemployed again means that multiple spells of unemployment are common. For example, our analysis of the cohort of individuals who became unemployed in 1993 reveals that over a four year window, job seekers were typically likely to experience two spells of unemployment. However, many job seekers experienced a larger number of spells (See table 3). For instance, slightly more than $10 \%$ experienced four spells of unemployment.

\section{Table 3. Number of Unemployment Spells in Four Years}

\begin{tabular}{cc}
\hline Percentiles & Number of spells \\
\hline 10 & 1 \\
20 & 1 \\
30 & 1 \\
40 & 1 \\
50 & 2 \\
60 & 2 \\
70 & 3 \\
80 & 3 \\
90 & 4 \\
\hline
\end{tabular}

\section{Time Unemployed}

The dynamics of unemployment presented above indicate that there are a variety of different patterns of unemployment. One useful means of bringing together these varying experiences of unemployment is to add up the total time individuals spend unemployed across the number of spells of unemployment that the job seeker has experienced see Table 4. This measure - the total time spent unemployed in four years - reveals that the time individuals spend unemployed is far greater than suggested by focussing on single spells of unemployment. Focussing on the one quarter of a million job seekers who became unemployed in 1993, we find that the median experience of unemployment was roughly 43 weeks. Indeed the majority - almost $70 \%$ of job seekers - experienced more than 26 weeks of unemployment.

\section{The Typical Unemployment Experience}

Our analysis provides insights into the overall incidence of unemployment. The data shows that an important minority of the population have some sort of experience of unemployment each year. For example, in the year of 1993 , roughly $10 \%$ of the working age population had some experience of registered unemployment.
There was, however, considerable variation in the severity of the unemployment experience for the cohort of individuals who became unemployed in 1993. In order to show this, we divide the 1993 cohort into four equal groups based on the total time spent unemployed. Table 5 shows the median length of total time unemployed for each of these groups, as well as the median number of spells and duration of the first spell of unemployment.

\section{Table 4. Total Time Unemployed in Four Years}

\begin{tabular}{cc}
\hline Percentiles & Total time unemployed \\
\hline 10 & 9.0 \\
20 & 15.0 \\
30 & 23.0 \\
40 & 31.3 \\
50 & 43.1 \\
60 & 57.6 \\
70 & 76.4 \\
80 & 102.3 \\
90 & 138.6 \\
\hline
\end{tabular}

As Table 5 shows, there was considerable variation in how individuals in the 1993 cohort experienced unemployment. For a quarter of job seekers, unemployment was a singular and relatively brief experience lasting around nine weeks. However, by way of contrast, a quarter of job seekers experienced chronic unemployment. Over four years, the typical job seeker in this group was unemployed three times, and experienced almost two and a half years of unemployment.

\section{Unemployment Across Social Groups}

The previous section described the typical patterns of registered unemployment for all groups of registered unemployment. This section looks at how these patterns vary between different social groups. In particular, we look at whether different demographic characteristics make individuals more or less likely to: become unemployed at least once in a year; spend a long time unemployed in their first spell; spend less time between spells of unemployment and thereby experience multiple spells of unemployment; experience more total time unemployed within four years.

\section{The Risk of Unemployment}

Our analysis reveals that there were important differences in the probability of becoming unemployed for different groups within the population in 1993. Table 6 reports the proportion of the working age population who had at least one experience of unemployment in 1993. Overall the risk of becoming unemployed was almost $9.7 \%$ in 1993 . However, a number of groups faced an above average risk of becoming unemployed. These groups included: males; all ethnic groups other than European/Pakeha; individuals younger than 30 years of age; individuals with low levels of educational qualifications; individuals living in Northland, the East Coast and other regions. 
Table 5. Summarising the Experience of the 1993 Cohort

\begin{tabular}{cccc}
\hline Quartiles & $\begin{array}{c}\text { Median total weeks } \\
\text { unemployed in four years } \\
\text { for each quartile }\end{array}$ & $\begin{array}{c}\text { Median number of spells for } \\
\text { each quartile }\end{array}$ & $\begin{array}{c}\text { Median length of first spell in } \\
\text { weeks for each quartile }\end{array}$ \\
\hline 1 & 9.1 & 1 & 9.0 \\
2 & 29.1 & 2 & 21.1 \\
3 & 61.9 & 2 & 28.1 \\
4 & 127.6 & 3 & 40.9 \\
\hline
\end{tabular}

Table 6. Probability of Becoming Unemployed in 1993

\begin{tabular}{lcc}
\hline N=255,747 & $\begin{array}{c}\text { Proportion } \\
\text { of job } \\
\text { seekers }\end{array}$ & $\begin{array}{c}\text { Proportion of } \\
\text { working age } \\
\text { population who } \\
\text { become } \\
\text { unemployed }\end{array}$ \\
\hline Female & 41.4 & 7.8 \\
Male & 58.6 & 11.7 \\
NZ European / Pakeha & 63.7 & 7.4 \\
Sole Maori & 18.0 & 25.8 \\
Mixed Maori & 7.3 & 25.8 \\
Pacific Peoples & 6.4 & 14.9 \\
Other & 4.6 & 14.1 \\
<20 & 21.6 & 20.6 \\
20-24 & 24.1 & 21.9 \\
25-29 & 15.5 & 15.1 \\
30-39 & 20.5 & 9.6 \\
40-49 & 12.0 & 6.8 \\
>50 & 6.3 & 1.9 \\
No formal school or & 42.3 & 11.0 \\
less than 3 years & & \\
secondary schooling & & \\
School certificate & 26.5 & 23.3 \\
Sixth form or other & 17.9 & 13.1 \\
school qualification & & \\
Post secondary or trade & 6.7 & 2.4 \\
qualification & & \\
Degree or professional & 6.6 & 5.3 \\
qualification & & \\
Auckland Central & 8.6 & 9.0 \\
Auckland North & 9.1 & 8.9 \\
Auckland South & 8.6 & 9.6 \\
Bay of Plenty & 8.9 & 11.6 \\
Canterbury & 9.8 & 7.9 \\
Central & 6.4 & 9.6 \\
East Coast & 7.3 & 14.2 \\
Nelson & 4.7 & 10.4 \\
Northland & 4.5 & 13.3 \\
Southern & 10.1 & 9.3 \\
Taranaki & 6.0 & 11.2 \\
Waikato & 7.1 & 9.0 \\
Wellington & 8.8 & 8.5 \\
\hline Total & $\mathbf{1 0 0}$ & $\mathbf{9 . 7}$ \\
\hline & & \\
\hline
\end{tabular}

Table 7. Duration of First Spell of Unemployment

\begin{tabular}{|c|c|c|}
\hline $\mathrm{N}=255,474$ & $\begin{array}{c}\text { Proportion } \\
\text { of job } \\
\text { seekers } \\
\end{array}$ & $\begin{array}{c}\text { Median duration } \\
\text { in weeks of single } \\
\text { spell }\end{array}$ \\
\hline Female & 41 & 15.9 \\
\hline Male & 59 & 21.1 \\
\hline $\begin{array}{l}\text { NZ European / } \\
\text { Pakeha }\end{array}$ & 64 & 17.9 \\
\hline Sole Maori & 18 & 22.4 \\
\hline Mixed Maori & 7 & 19.1 \\
\hline Other & 5 & 17.9 \\
\hline Pacific Peoples & 6 & 21.7 \\
\hline$<20$ & 21 & 17.6 \\
\hline $20-24$ & 24 & 19.7 \\
\hline $25-29$ & 15 & 18.6 \\
\hline $30-39$ & 20 & 18.4 \\
\hline $40-49$ & 12 & 18.6 \\
\hline$>50$ & 6 & 21.1 \\
\hline $\begin{array}{l}\text { No formal school or } \\
\text { less than } 3 \text { years } \\
\text { secondary schooling }\end{array}$ & 42 & 21.4 \\
\hline $\begin{array}{l}\text { Less than } 3 \text { School } \\
\text { Cert. passes or } \\
\text { equivalent }\end{array}$ & 14 & 18.0 \\
\hline $\begin{array}{l}\text { Three or more School } \\
\text { Cert. passes or } \\
\text { equivalent }\end{array}$ & 13 & 17.0 \\
\hline $\begin{array}{l}\text { Sixth Form Cert., UE } \\
\text { or equivalent, } \\
\text { Bursary, HSC }\end{array}$ & 16 & 17.6 \\
\hline $\begin{array}{l}\text { Other school } \\
\text { qualifications }\end{array}$ & 2 & 15.9 \\
\hline $\begin{array}{l}\text { Post secondary or } \\
\text { trade qualification }\end{array}$ & 7 & 16.4 \\
\hline $\begin{array}{l}\text { Degree or } \\
\text { professional } \\
\text { qualification }\end{array}$ & 7 & 16.9 \\
\hline Auckland Central & 9 & 17.7 \\
\hline Auckland North & 9 & 16.1 \\
\hline Auckland South & 9 & 19.6 \\
\hline Bay of Plenty & 9 & 19.0 \\
\hline Canterbury & 10 & 19.1 \\
\hline Central & 6 & 18.1 \\
\hline East Coast & 7 & 18.1 \\
\hline Nelson & 5 & 18.4 \\
\hline Northland & 5 & 20.0 \\
\hline Southern & 10 & 19.9 \\
\hline Taranaki & 6 & 17.9 \\
\hline Waikato & 7 & 19.1 \\
\hline Wellington & 9 & 20.4 \\
\hline Total & 100 & 18.7 \\
\hline
\end{tabular}


Apart from differences in the risk of becoming unemployed, there were also important differences in the duration of unemployment for the cohort of individuals who became unemployed in 1993. Table 7 reports differences in the median length of first unemployment spell for different groups of job seekers.

\section{Table 8. Median Duration of the Off-register Spell}

\begin{tabular}{|c|c|c|}
\hline $\mathrm{N}=269,989$ & $\begin{array}{c}\text { Proportion of } \\
\text { job seekers } \\
(\%)\end{array}$ & $\begin{array}{l}\text { Median length } \\
\text { of the off- } \\
\text { register spell in } \\
\text { weeks }\end{array}$ \\
\hline Female & 40.5 & 116.1 \\
\hline M ale & 59.5 & 55.0 \\
\hline $\begin{array}{l}\text { NZ European / } \\
\text { Pakeha }\end{array}$ & 64.4 & 109.1 \\
\hline Sole M aori & 17.7 & 32.6 \\
\hline$M$ ixed $M$ aori & 7.4 & 46.9 \\
\hline Pacific Peoples & 6.4 & 62.6 \\
\hline Other & 4.1 & 145.1 \\
\hline$<20$ & 22.6 & 38.4 \\
\hline $20-24$ & 23,4 & 76.3 \\
\hline $25 \cdot 29$ & 15.2 & 92.9 \\
\hline $30-39$ & 19.6 & 99.3 \\
\hline 40.49 & 11.5 & 142.0 \\
\hline$>50$ & 6.0 & DNR \\
\hline $\begin{array}{l}\text { No formal school or } \\
\text { less than } 3 \text { years } \\
\text { secondary schooling }\end{array}$ & 42.4 & 44.4 \\
\hline $\begin{array}{l}\text { Less than } 3 \mathrm{School} \\
\text { Cert. passes or } \\
\text { equivalent }\end{array}$ & 13.8 & 57.0 \\
\hline $\begin{array}{l}\text { Three or more School } \\
\text { Cert.passes or } \\
\text { equivalent }\end{array}$ & 13.1 & 97.0 \\
\hline $\begin{array}{l}\text { Sixth Form Cert., UE } \\
\text { or equivalent, } \\
\text { Bursary, HSC }\end{array}$ & 15.9 & 131.1 \\
\hline $\begin{array}{l}\text { Other school } \\
\text { qualifications }\end{array}$ & 1.7 & 167.0 \\
\hline $\begin{array}{l}\text { Post secondary or } \\
\text { trade qualification }\end{array}$ & 7.1 & D N R \\
\hline $\begin{array}{l}\text { Degree or } \\
\text { professional } \\
\text { qualification }\end{array}$ & 6.0 & D N R \\
\hline A uckland Central & 8,6 & 154.0 \\
\hline A uckland North & 9.7 & 191.0 \\
\hline A uckland South & 8.8 & 85.4 \\
\hline B ay of Plenty & 9.0 & 53.0 \\
\hline Canterbury & 9.7 & 113.7 \\
\hline Central & 6.3 & 70.2 \\
\hline East Coast & 7.1 & 31.9 \\
\hline Nelson & 4.6 & 46.0 \\
\hline Northland & 4.6 & 45.7 \\
\hline Not Recorded & 0.0 & 42.4 \\
\hline Southern & 9.9 & 54.6 \\
\hline Taranaki & 5.9 & 51.3 \\
\hline W aikato & 7.3 & 68.9 \\
\hline Wellington & 8.7 & 106.6 \\
\hline Total & 100.0 & 74.7 \\
\hline
\end{tabular}

Note: DNR $=$ Did not return within 4 years

Our analysis reveals a number of groups faced a higher risk of unemployment. These included: male job seekers; individuals of sole Maori or Pacific Peoples ethnicity; mature workers aged over 50 years; individuals with no formal qualifications; individuals living in Northland and Wellington regions.

There are also considerable differences in the median duration of time between the finish of one spell and the be- ginning of another for different groups. Table 8 shows the median duration of the non-unemployment spell for different demographic groups. Our analysis reveals considerable differences. Typically, the groups who were more likely to become unemployed again were: males; sole and mixed Maori, and to a lesser extent Pacific Peoples Job seekers; job seekers under 20 years of age; individuals with low levels of qualifications; job seekers in the Bay of Plenty, East Coast, Nelson, Northland, the Southern region, and Taranaki.

The conclusions from the analysis of the differing time between unemployment spells is also reinforced by looking at the typical number of spells of unemployment experienced by different groups. Those groups more at risk of

\section{Table 9. Median Total Time Unemployed for the Cohort who Enrolled in 1993}

\begin{tabular}{|c|c|c|}
\hline & $\begin{array}{l}\text { Number of } \\
\text { job seekers }\end{array}$ & $\begin{array}{c}\text { Median total } \\
\text { weeks } \\
\text { unemployed in } \\
\text { four years }\end{array}$ \\
\hline Female & 41.4 & 34.0 \\
\hline Male & 58.6 & 51.9 \\
\hline Mixed Maori & 7.3 & 53.1 \\
\hline NZ European / Pakeha & 63.7 & 36.9 \\
\hline Other & 4.6 & 36.4 \\
\hline Pacific Peoples & 6.4 & 51.0 \\
\hline Sole Maori & 18.0 & 68.7 \\
\hline$<20$ & 21.2 & 55.7 \\
\hline $20-24$ & 23.6 & 41.7 \\
\hline $25-29$ & 15.2 & 38.9 \\
\hline $30-39$ & 20.2 & 40.1 \\
\hline $40-49$ & 11.8 & 38.7 \\
\hline$>50$ & 6.2 & 35.1 \\
\hline $\begin{array}{l}\text { No formal school or } \\
\text { less than } 3 \text { years } \\
\text { secondary schooling }\end{array}$ & 42.3 & 58.1 \\
\hline $\begin{array}{l}\text { Less than } 3 \text { School } \\
\text { Cert. passes or } \\
\text { equivalent }\end{array}$ & 13.7 & 46.0 \\
\hline $\begin{array}{l}\text { Three or more School } \\
\text { Cert. passes or } \\
\text { equivalent }\end{array}$ & 12.7 & 36.7 \\
\hline $\begin{array}{l}\text { Sixth Form Cert., UE } \\
\text { or equivalent, Bursary, } \\
\text { HSC }\end{array}$ & 16.3 & 33.6 \\
\hline $\begin{array}{l}\text { Other school } \\
\text { qualifications }\end{array}$ & 1.7 & 30.4 \\
\hline $\begin{array}{l}\text { Post secondary or trade } \\
\text { qualification }\end{array}$ & 6.7 & 29.0 \\
\hline $\begin{array}{l}\text { Degree or professional } \\
\text { qualification }\end{array}$ & 6.6 & 26.6 \\
\hline A uckland Central & 8.6 & 35.9 \\
\hline A uckland North & 9.1 & 31.1 \\
\hline A uckland South & 8.6 & 44.0 \\
\hline B ay of Plenty & 8.9 & 47.9 \\
\hline Canterbury & 9.8 & 38.3 \\
\hline Central & 6.4 & 44.4 \\
\hline East Coast & 7.3 & $\begin{array}{l}56.7 \\
15.0\end{array}$ \\
\hline $\begin{array}{l}\text { Nelson } \\
\text { Northland }\end{array}$ & $\begin{array}{l}4.7 \\
4.5\end{array}$ & $\begin{array}{l}45.9 \\
56.1\end{array}$ \\
\hline $\begin{array}{l}\text { Northland } \\
\text { Southern }\end{array}$ & $\begin{array}{c}4.5 \\
10.1\end{array}$ & $\begin{array}{l}56.1 \\
46.6\end{array}$ \\
\hline Taranaki & 6.0 & 48.9 \\
\hline W aik a to & 7.1 & 44.1 \\
\hline W ellington & 8.8 & 40.3 \\
\hline Total & 100 & 43.1 \\
\hline
\end{tabular}


returning to the register also seemed to experience more spells of unemployment.

As argued previously, because of the existence of multiple spells of unemployment, the overall risk of unemployment for individuals who become unemployed can usefully be summarised by measuring the total time spent unemployed in four years. For individuals who become unemployed this measure captures both the risk of a long spell of unemployment, as well as a higher risk of rapidly becoming unemployed again. Table 9 provides information on the median total time unemployed in the following four years for different groups.

Table 9 shows a number of groups as having a high risk of total levels of unemployment. These groups include: male job seekers; sole and mixed Maori as well as Pacific Peoples job seekers; young people; individuals with low levels of qualifications; individuals resident in Northland and the East Coast.

\section{Summary}

Our analysis has revealed important differences in the unemployment experiences of different groups. Here we have tried to summarise this information by demographic group.

- Males seem to be more at risk of becoming unemployed than females. Moreover, once becoming unemployed, there is a greater risk of having a longer spell of unemployment, having multiple spells of unemployment, and as a result spending more time unemployed in total.

- Sole Maori, and to a lesser extent mixed Maori and Pacific peoples are at risk of prolonged periods of unemployment in comparison to the rest of the population. There are also interesting differences in how unemployment is experienced between sole and mixed Maori. Both have a high risk of becoming unemployed. However, once unemployed, sole Maori are more likely to experience longer spells of unemployment and more likely to experience multiple spells. As a result, in comparison to mixed Maori, sole Maori suffer a longer total time unemployed.

- Younger workers face a higher risk of becoming unemployed that older workers. However, mature workers are at risk of a longer spell of unemployment once they are unemployed. Nevertheless, despite this, younger workers are more at risk of multiple spells of unemployment, and as a result more at risk of spending a larger total time unemployed than older workers.

- Job seekers with low levels of qualifications are more at risk of becoming unemployed, and once becoming unemployed, are more likely to have a longer duration of unemployment, multiple spells, and spend longer on the register in total.
- In comparison to other regions, individuals in Northland and the East Coast are more at risk of becoming unemployed and also spending a longer total time unemployed.

There are, however, a number of reasons why some care must be taken in the interpretation of results discussed above.

First, we report differences in the typical experience for different groups. However, as is discussed in the preceding sections, there is a great deal of variation in unemployment experiences. There is a wide variation in the unemployment experiences within each group that is disguised by a focus of group averages.

Second, differences in typical outcomes between groups do not always imply that the particular demographic characteristics are causes of labour market disadvantage. For example, consider the fact that Maori seem to have poorer unemployment outcomes than Pakeha. Ethnic characteristics may play some role in these poorer outcomes (for example through discrimination), but equally, Maori are more likely to live in economically depressed areas and have lower levels of qualifications, and these other characteristics may also have some impact on the difference in average outcomes between Maori and Pakeha.

Third, we focus here on the cohorts of job seekers who became unemployed or leave unemployment in 1993. It is important to note that the differences we observe may change over time. For example, we investigate regional differences in the unemployment experience of job seekers. Given differing growth rates of regions, we would expect that some conclusions derived from an analysis of the 1993 cohorts would not necessarily hold for different time periods.

\section{Changing Dynamics of Unemployment}

So far our analysis of the dynamics of unemployment has focussed on the experiences of a cohort of people entering a particular year (1993). An important question is whether over time there have been changes in the risk of: becoming unemployed; spending a longer period of time in their current spell of unemployment and ; becoming unemployed again.

In order to answer these questions, we compared unemployment experiences of cohorts over the three distinct phases of the economy. From the late 1980s to 1992 the economy was in recession and the level of unemployment rose significantly. We have called this the recession period. From 1992 to 1996 the economy was growing and the level of unemployment declined sharply. We have called this the growth period. From 1996 to 1997 the economy was mildly recessionary and the overall level of unemployment increased again. We have called this the flat period. 
The probability of individuals becoming unemployed followed the economic cycle as would be expected. The recessionary period saw the risk of becoming unemployed rising sharply. The risk of unemployment reduced during the growth period, but began climbing again during the growth flat period.

Changing economic conditions also affected the median duration of unemployment spells. The median duration of unemployment increased during the recessionary period, and decreased during the growth period.

Lastly, the length of time between spells of unemployment also followed the state of the economy. The risk of job seekers returning to the register was greater during times of reduced economic prospects. Conversely, when the economy was growing there was a lower risk of job seekers returning to the register.

\section{Conclusion}

In this paper we have looked at the experiences of the unemployed by following groups of registered job seekers over time. The main part of our research has focused on the cohort of individuals who became registered unemployed in 1993.

We found that unemployment was experienced by roughly $10 \%$ of the working age population in 1993 . There was, however, considerable variation in how individuals in this cohort experienced unemployment. For a quarter of job seekers, unemployment was a singular and relatively brief experience lasting around nine weeks. However, by way of contrast, a quarter of job seekers also experienced chronic unemployment. Over four years, the typical job seeker in this group was unemployed three times, and experienced almost two and a half years of unemployment. In addition, our analysis showed that unemployment is concentrated in particular groups in the community, in particular: males; Maori and Pacific peoples job seekers; job seekers with low levels of qualifications; individuals aged under 20 and over 50 years; individuals living in Northland and the East Coast.

Over time, as we would expect, the typical experiences of the unemployed tend to change with the economic cycle. During recoveries, typically the risk of unemployment and the duration of unemployment spells fall, while the typical time spent between unemployment spells rises. The reverse results occur during down turns.

\section{Future Research}

In this paper, we have discussed descriptive results on unemployment experiences by different demographic characteristics. However, differences in typical outcomes between groups do not always imply that the particular demographic characteristics are causes of labour market disadvantage. For example, consider the fact that Maori seem to have poorer unemployment outcomes than Pakeha. Eth- nic characteristics may play some role in these poorer outcomes, but equally, Maori are more likely to live in economically depressed areas and have lower levels of qualifications, and these other characteristics may also have some impact on the difference in average outcomes between Maori and Pakeha. Accordingly, it would be useful to undertake a regression analysis to look at how different demographic characteristics affect unemployment experiences. David Rea and Dave Mare have already started some preliminary research on this and further research in this area is planned for the future.

Another avenue for future research would be to extend our database to gain more information on the experiences of the unemployed. Our database does have some limitations. A useful way to extend our database would be to combine it with benefit data from the Department of Work and Income. For instance, currently our database has limited information on what happens to job seekers when they leave unemployment. Including benefit data would help us to see whether job seekers move to other benefits when they leave the register and it may also provide more information on the employment opportunities gained by the job seekers. Accordingly, we are hoping to extend the dataset in the future.

\section{Notes}

1 The authors would like to thank Andrew Purser, James Macnaughton, Andrew Reynolds, Moira Wilson, Dave Mare, Toby Buscombe, Michael Hampl, and Richard Downing for their assistance with this research. The authors retain sole responsibility for any errors. Any views expressed are our own and do not necessarily reflect those of our employers.

2 The labour force includes both those who are employed and those who are unemployed. This means that it does not include individuals who are not actively seeking and available for work.

3 In other words, $50 \%$ of job seekers ended their spell of unemployment within 19 weeks, while the remaining $50 \%$ of job seekers experienced longer duration.

4 Note that we have focussed on the first unemployment spell for our analysis as job seekers are more likely to have completed their first spell in the four year period, than any subsequent spells. The first spell of unemployment here refers to the individuals' first spell of unemployment in the four year period starting from 1993. Some of the job seekers may have experienced unemployment spells prior to 1993.

4 In this section, we focus on the group of people who left the register in 1993. The results in this section refer to their first off the register spell in the four year period from 1993 onwards. As noted above for 
spells of unemployment, we have focussed on the first off the register spell for our analysis as job seekers are more likely to have completed this spell in the four year period, than any subsequent spells.

6 In order to show the typical experiences of job seekers in each quartile, we have focussed on the median figures for each quartile.

7 The working age population here refers to those who are aged 15 years and over. Accordingly, the risks of unemployment here are unstated as the working age population includes retired people.

8 Sole Mäori refer to individuals who identify themselves as being of only the Mäori ethnic group, while mixed Mäori refers individuals who identify themselves as being both Mäori and another ethnic group.

9 For our analysis of age data, we have focussed on an individual's age at their time of enrolment.

10 It is our view that the low risk of multiple spells and total time unemployed for mature age workers may be the result of the eligibility requirements for the $55+$ benefit. This benefit does not require registration after 6 months upon turning 55 years of age.

\title{
Authors
}

\author{
Maria Gobbi \\ Analyst \\ Labour Market Policy Group \\ Department of Labour \\ P O Box 3705 \\ Wellington \\ Maria.Gobbi@Impg.dol.govtnz \\ David Rea \\ Senior Strategic Policy Analyst \\ Policy Department \\ Ministry of Social Policy \\ Private Bag 39993 \\ Wellington \\ David.Rea001@mosp.govt.nz
}

